\author{
親松 裕典, 大畑 賀央, 成田久仁夫
}

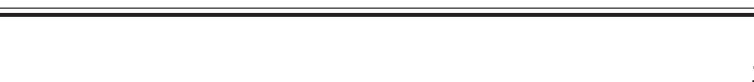
要 旨

背景. 脊髄梗塞の発症は稀であるが, 硬膜外麻酔併用全身麻酔手術後に発症した報告が散見される.

症例. 70 歳代, 男性. 右上葉の肺癌に対して硬膜外麻酔併用全身麻酔下で右 S2 区域切除を行った. 術後第 1 病日から右下 肢筋力低下, 右半身の乳嘴から下肢までの知覚低下がみられ, 持続硬膜外麻酔薬注入の中断後も継続した. Th6-8の不完全型 Brown-Sequard 症候群がみられ, MRI でTh6-8に脊髄梗塞を認めた. 硬膜外カテーテルを抜去し, 抗凝固療法, 抗浮腫薬点 滴, リハビリ治療を行うことで膀胱直腸障害は軽快し, 下肢筋力は歩行可能にまで改善した.

結論. 脊髄梗塞は麻酔や手術に起因し得る病態であるため, 高齢, 動脈硬化, 糖尿病, 脂質異常症, 喫煙, 脳梗塞, 冠動 脈疾患, 癌等の危険因子をもつ患者では注意が必要である。また硬膜外麻酔も発症の一因となる可能性があるため, その適 応にも慎重になるべきと考えられる.
\end{abstract}

索引用語 : 胸部手術, 硬膜外麻酔, 脊䯣梗塞, ブラウンセカール症候群

thoracic surgery, epidural anesthesia, spinal cord infarction, Brown-Sequard syndrome

\section{はじめに}

脊髄梗塞は稀であるが, 硬膜外麻酔併用全身麻酔手術 後に脊髄梗塞の発症が報告されている ${ }^{1-5)}$. 今回, 硬膜外麻 酔併用全身麻酔下で肺区域切除後に発症した脊髄梗塞を 経験した，危険因子を持つ患者に，麻酔や手術で発症す る可能性があり, 注意が必要と考えたため報告する.

\section{症例}

症 例: 70 歳代, 男性.

既往歴：胃癌, 狭心症, 糖尿病.

生活歴：喫煙 60 本/日 $\times 40$ 年.

現病歴：胃癌にて幽門側胃切除術後 1 年の CT で右上 葉に結節影を指摘され，手術目的で紹介となった。

麻酔所見：硬膜外麻酔併用全身麻酔を行った．硬膜外 麻酔はTh8/9 に傍正中法で, トラブルなくカテーテルを 留置し, ロピバカインを術中/術後に持続注入した. 血圧

豊橋市民病院呼吸器外科

原稿受付 2016年 1 月 6 日

原稿採択２016年 2 月15日
は 80-120 mmHg 程度で循環管理した。

手術所見：胸腔鏡補助下に右 S2 区域切除と ND1b 郭 清を行った，術中に肋間動脈を触ることなく，気管支動 脈は上葉支分岐末梢で切離した. 出血量は少量であった. 病理診断では扁平上皮癌, 郭清リンパ節に転移はなかっ た。

術後経過：術後第 1 病日に右下肢筋力低下, 右側半身 の乳嘴から下肢にかけ知覚低下がみられた。麻酔薬の硬 膜外持続注入を中断したが, 術後第 2 病日にも症状は改 善しなかった. 詳細な身体所見をとると, Th6-8 の不完全 型 Brown-Sequard 症候群 (右下肢の筋力低下, 触覚は右 Th6-8 で脱失, 左 Th6-8 と右 Th9 以下で低下, 痛覚は左 右 Th6-8 で脱失, 左下肢で低下, 深部感覚は右下肢で低 下）と膀胱直腸障害を認めた，MRI で Th6-8 に春髄梗塞 が確認された (Fig. 1). 硬膜外カテーテル抜去後に, 浸透 圧利尿薬点滴とへパリン持続点滴を開始した。術後第 5 病日にヘパリン持続点滴からアスピリン内服にした。感 覚障害は残存したが,リハビリにより膀胱直腸障害は軽 快し，下肢筋力は歩行可能にまで改善した．術後第 24 病日に退院し，通院リハビリを継続した。 

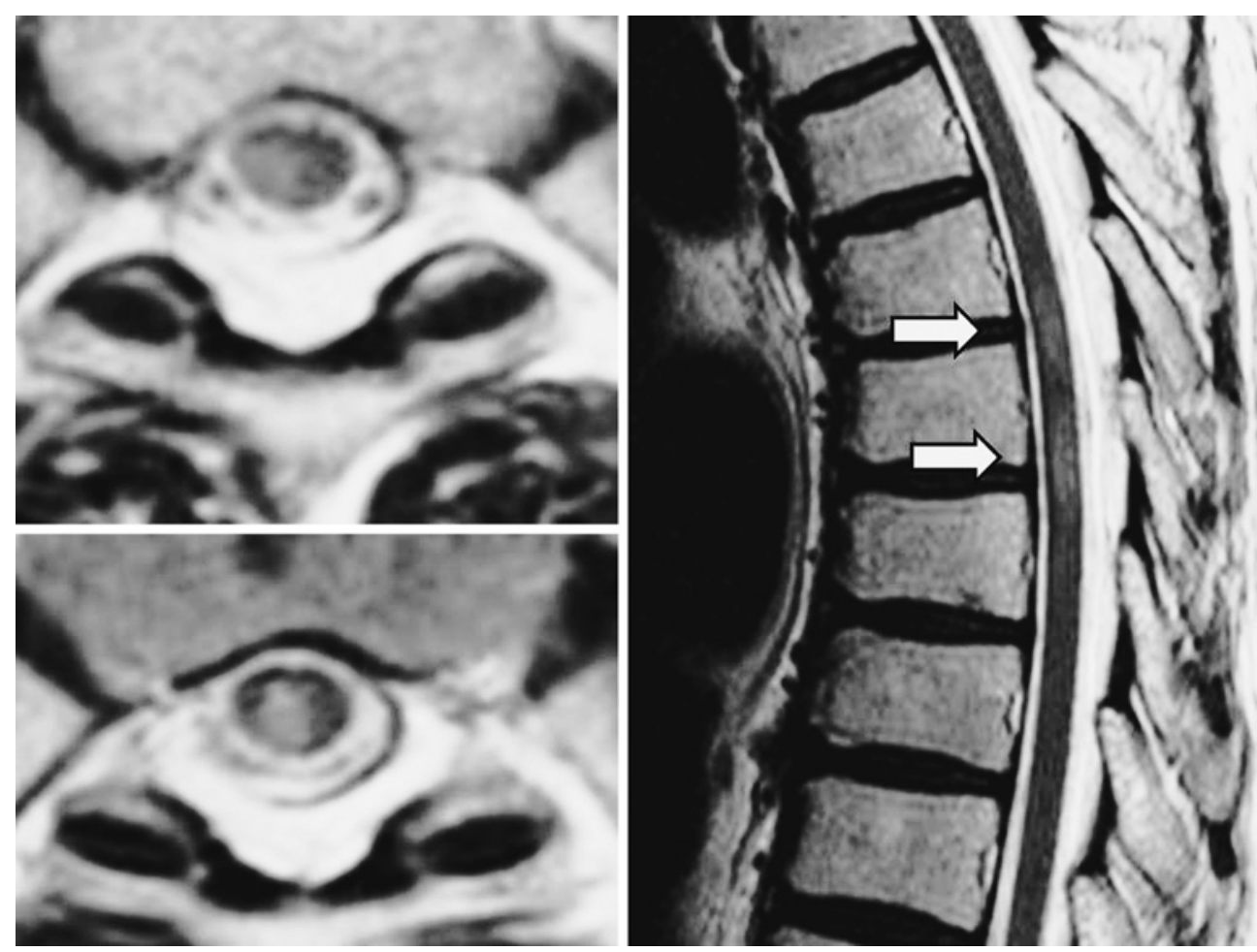

Fig. 1 MRI showing spinal cord infarction at Th6-8.

考

察

脊髄梗塞は脊䯣の血流障害による急性脊髄障害, 脊髄 実質の壊死で, その頻度は急性脊髄障害の 5-8\%, 全脳卒 中の $1-2 \%$ と稀である ${ }^{6}$. 障害部位により運動麻痺, 感覚 障害, 膀胱直腸障害が出現する. 予後は病巣の広がりに よるが, リハビリで運動機能と膀胱直腸障害はある程度 回復するが, 後遺症として残ることが多い ${ }^{6.8}$. 治療は確立 したものはないが, 超急性期の血栓融解療法, 急性期の 抗凝固療法, 脊髄浮腫予防に浸透圧利尿薬やステロイド が用いられる. 早期からのリハビリが重要で, 早期診断/ 治療が望ましい ${ }^{7.8)}$.

脊髄の栄養動脈は肋間動脈等の分節動脈から脊髄枝が 分かれ, 前脊髄動脈と後脊髄動脈を形成する. 多くの脊 髄枝は脊䯣内部に到達せずに退縮し, 脊髄に達するもの は左右で各々 $5 \sim 8$ 本程度となる. Th9-L1 付近の下行大 動脈から分岐する Adamkiewicz 動脈は重要である. 脊 髄腹側 $2 / 3$ を前脊髄動脈が, 背側 $1 / 3$ を後脊髄動脈が栄 養する，前脊髄動脈は中心動脈になり左右の脊髄腹側を 栄養するが, これが障害されると左右非対称の虚血とな $ろ^{6.8)}$. 本症例は MRI で Th6-8 の右半側, 中心〜後方に脊
髄梗塞を認め, 中心動脈または右後脊髄動脈由来と考え られた。春髄梗塞の危険因子として, (1)高齢, (2)動脈硬 化, (3)糖尿病, (4)脂質異常症, (5)契煙, (6)脳梗塞, (7)冠 動脈疾患，(8)癌等が挙げられる (3)，(5)，(7)，8該当し，危険因子を多く備えていた. これに麻酔や手術による影響が重なり発症した可能性が ある。

呼吸器外科手術による原因として, 気管支動脈と肋間 動脈が共通幹を形成している場合の気管支動脈切断 ${ }^{2.3}$ や 大量出血で生じる可能性がある。本症例の障害部位は Th6-8であり, 上位胸髄の栄養動脈と Adamkiewicz 動脈 の脊髄長軸方向の分水嶺のレベルと考えられ, 肋間動脈 損傷により上位胸䯣の栄養動脈血流減少で発症した可能 性は否定し得ないが, 術中に肋間動脈損傷はなく, 気管 支動脈切断部も上葉気管支が分岐した末梢であり考えに くい.また術中出血量も少量であった.

一方, 麻酔による原因として, 術中の血圧変動や硬膜 外麻酔による可能性がある. 麻酔中の血圧低下は一般的 によく起こるが, 脊髄虚血が起こる低血圧限界は低く, 40-50 mmHg 程度でも虚血は生じにくいとされる7). 本症 例の術中血圧は 80-120 mmHg 程度に循環管理されてお 
り, これも可能性は低い. 硬膜外麻酔と脊髄梗塞の因果 関係は明らかでないが, 原因として, 穿刺やカテーテル 挿入による根動脈の圧迫や損傷, 薬物による根動脈の攣 縮, 硬膜外腔への薬物投与やカテーテル挿入による硬膜 外腔のコンプライアスンス低下・圧上昇のため起きる宜 髄栄養血管の血流障害の可能性が指摘されている ${ }^{4)}$. 本症 例で硬膜外麻酔の手技や使用は問題なかったが, 梗塞レ ベル近傍から刺入しており, 微小な血管損傷, 留置カテー テルによる圧迫や薬液による血流障害の可能性は残る。

本症例では明らかな原因を特定できないが, 複数の危 険因子を持つ患者に麻酔や手術などの複合的な要因が契 機となり発症した可能性がある，硬膜外麻酔による脊髄 梗塞発症や神経症状発見の遅れの可能性 ${ }^{5}$ から, 危険因子 を多く持つ患者の硬膜外麻酔適用は慎重になるべきと考 えられる. その場合, 創部痛が減ずるよう胸腔鏡下手術 の適応や, 硬膜外麻酔の代替として術野からの神経ブ ロック，鎮痛薬投与での術後鎮痛が望ましいと考える.

本症例の経験を契機に, 現在当施設では硬膜外麻酔を 控えており, その代用として肋間神経ブロックや経静脈 鎮痛薬（フェンタニル単剂またはアセトアミノフェン併 用）を用いている.

\section{利益相反}

本論文について申告する利益相反はない.

\section{文献}

1. Chan LL, Kumar AJ, Leeds NE, Forman AD. Postepidural analgesia spinal cord infarction: MRI correlation. Acta Neurol Scand 2002; 105: 344-8.

2. 西井竜彦, 村松 高, 四万村三恵, 古市基彦, 大森一光, 塩野元美. 左肺癌術後に衤髄梗塞を来した一例. 日呼外会 誌 2010; 24: 972-5.

3. 横田圭右, 齋藤雄史, 佐竹 章, 山川洋右. 左上葉切除術 後に脊髄梗塞を発症した一例。 日呼外会誌 2015; 29: 4759.

4. 神移 佳, 瀧 康則, 明星康裕, 遠山一喜. 硬膜外麻醉併 用全身麻酔後に脊髄梗塞が明らかになった 1 症例。臨床 麻酔 2005; 29: 1772-4.

5. 古賀由香利, 平木照之, 牛島一男. 硬膜外併用全身麻酔下 の肝切除術後に脊髄梗塞による対麻痺を来した 1 症例. 麻酔 2015; 64: 396-9.

6. 佐藤慶史郎, 内山 剛. 脊鹃血管障害, 循環障害 脊髄梗 塞. 水澤英洋編. 神経症候群 I. 第 2 版. 大阪 : 日本臨牀 社 ; 2014: 390-3.

7. 谷 諭. 脊髄梗塞 脊髄外科医でも知っておくべきこ と. 脊椎脊髄ジャーナル 2005; 18: 971-7.

8. 安藤哲朗, 稲垣智則, 杉浦 真. 脊髄血管障害, 循環障害 前脊髄動脈症候群. 水澤英洋編. 神経症候群 I. 第 2 版. 大阪：日本臨林社；2014: 394-7.

9. 冨永悌二, 高橋敏行. 脊䯣血管障害の臨床像. 脊椎脊髄 ジャーナル 2005; 18: 526-9. 


\title{
Spinal cord infarction after segmentectomy under general-epidural anesthesia
}

\author{
Hironori Oyamatsu, Norihisa Ohata, Kunio Narita \\ Department of Respiratory Surgery, Toyohashi Municipal Hospital
}

Background. Spinal cord infarction is rare. There are some reports of spinal cord infarction occurring after an operation under general-epidural anesthesia.

Case. A septuagenarian man underwent right S2 segmentectomy under general-epidural anesthesia. He suffered from right leg muscle weakness and imperception from the right nipple to lower limb since the 1st postoperative day. These symptoms continued after the discontinuation of epidural anesthesia. He was diagnosed with incomplete BrownSequard syndrome at Th6-8 and his spinal cord infarction was proven by MRI. The epidural catheter was removed and he underwent anticoagulant therapy, antihydropic therapy, and rehabilitation treatment. Vesicorectal disorder was relieved and he became ambulatory due to improvement of the leg muscle strength.

Conclusions. Spinal cord infarction can be caused by anesthesia or surgery, and it is necessary to pay attention to patients with risk factors: advanced age, arteriosclerosis, diabetes, dyslipidemia, smoking, cerebral infarction, coronary heart disease, and cancer. Because of a potential for spinal cord infarction, the indication of epidural anesthesia should be decided carefully. 